\title{
The core of the Nordic health care system is not empty
}

\author{
CARL HAMPUS LYTTKENS ${ }^{1,}$ * \\ TERKEL CHRISTIANSEN ${ }^{2}$ \\ UNTO HÄKKINEN ${ }^{3}$ \\ ODDVAR KAARBOE ${ }^{4}$ \\ MATT SUTTON ${ }^{5}$ \\ ANNA WELANDER ${ }^{1}$ \\ ${ }^{1}$ Department of Economics, Lund University, Sweden \\ ${ }^{2}$ Centre of Health Economics Research, University of Southern Denmark \\ ${ }^{3}$ Centre for Health and Social Economics, National Institute for Health and Welfare, Helsinki, Finland \\ ${ }^{4}$ Department of Health Management and Health Economics, University of Oslo, Norway \\ ${ }^{5}$ Manchester Centre for Health Economics, University of Manchester, UK
}

\begin{abstract}
The Nordic countries are well-known for their welfare states. A very important feature of the welfare state is that it aims at easy and equal access to adequate health care for the entire population. For many years, the Nordic systems were automatically viewed as very similar, and they were placed in the same group when the OECD classified health care systems around the world. However, close inspection soon reveals that there are important differences between the health care systems of Denmark, Finland, Iceland, Norway and Sweden. Consequently, it is perhaps no surprise that the Nordic countries fell into three different categories when the OECD revised its classification a few years ago. In this paper, we revisit this issue and argue that the most important similarity across the Nordic countries is the institutional context in which the health care sector is embedded. Nordic health care exists in a high-trust, high-taxation setting of small open economies. With this background, we find a set of important similarities in the manner in which health care is organized and financed in the Nordic countries. To evaluate the performance of the Nordic health care system, we compare a few health quality indicators in the Nordic countries with those of five non-Nordic similarly small open European economies with the same level of income. Overall, the Nordic countries seem to be performing relatively well. Whether they will continue to do so will depend to a large extent on whether the welfare state will continue to reform itself as it has in the past.
\end{abstract}

JEL classification: I11, I13, I18, I38

Key words: Nordic health care system, embedded, trust, quality, efficiency, institutions

\section{Introduction}

Denmark, Finland, Iceland, Norway, and Sweden are collectively known as the "Nordic countries". These five countries have much in common. They are small open economies, sparsely populated, with long traditions of democratic rule. They are also welfare states. In this paper, we will discuss whether the characteristics of the health care sector in these five countries motivate the use of the expression "the Nordic Health Care system" - are they

* Correspondence to: Carl Hampus Lyttkens, Department of Economics, P.O. Box 7082, SE- 220 07 Lund, Sweden. E-mail: carl_hampus.lyttkens@nek.lu.se

dx.doi.org/10.5617/njhe. 2848 
sufficiently similar and if so, what are the characteristics of this system? The Nordic countries are often used as a point of reference for other health care systems (Toth, 2010). The inclusion of Iceland in our analysis adds value compared to previous studies of Nordic health care systems.

Many scholars have used the old OECD classification system, in which there were three groups of countries and the five Nordic countries were all placed in the same category (public integrated systems). However, a recent study by the OECD results in six new categories and the Nordic countries are split between three of these six categories (Joumard et al., 2010). We will argue, however, that Nordic societies and health care sectors display many similarities and that they have an important common core. Consequently, it is reasonable to speak in terms of a Nordic health care system, despite some significant differences between the Nordic countries in how they organize and finance their health care.

This paper, together with four companion papers in this issue of the Nordic Journal of Health Economics, explores key aspects of the health care systems in the Nordic countries. The point of comparison will be the OECD countries. However, when we come to the issue of comparing quality in health care, we will argue that a more restricted comparison is appropriate. All Nordic systems are decentralized, which makes an exact description of their health care system(s) an almost impossible task. ${ }^{1}$ Nevertheless, we think that it is a useful endeavour to pinpoint the most important similarities and differences between the Nordic countries.

The inhabitants of the Nordic countries have a high life expectancy at birth, and a high percentage of the population report to being in good health (Table 1). ${ }^{2}$ With the main exception of obesity in Iceland, the inhabitants of the Nordic countries generally display healthier behaviour than the OECD average. These differences in lifestyle are analysed in one of the companion papers (Ásgeirsdóttir and Gerdtham, this issue).

Table 1: Health and life-style in the Nordic countries and the OECD, 2011

\begin{tabular}{|c|c|c|c|c|c|c|}
\hline & Denmark & Finland & Iceland & Norway & Sweden & $\begin{array}{l}\text { OECD } \\
\text { average }\end{array}$ \\
\hline Life expectancy at birth, women & 81.9 & 83.8 & 84.1 & 83.6 & 83.8 & 82.8 \\
\hline Life expectancy at birth, men & 77.8 & 77.3 & 80.7 & 79.1 & 79.9 & 77.3 \\
\hline $\begin{array}{l}\% \text { adults in good health, self- } \\
\text { reported, women }\end{array}$ & 69.0 & 67.7 & 76.1 & 71.1 & 78.0 & 66.6 \\
\hline $\begin{array}{l}\% \text { adults in good health, self- } \\
\text { reported, men }\end{array}$ & 73.1 & 70.5 & 79.4 & 75.4 & 81.8 & 71.5 \\
\hline $\begin{array}{l}\text { Tobacco adults, } \% \text { of population, } \\
\text { smoking daily }\end{array}$ & 20.0 & 17.8 & 14.3 & 17.0 & 13.1 & 20.9 \\
\hline $\begin{array}{l}\text { Alcohol adults, litres per capita per } \\
\text { year }\end{array}$ & 10.6 & 9.8 & 7.3 & 6.6 & 7.4 & 9.4 \\
\hline $\begin{array}{l}\text { Obesity adults, } \% \text { of population, a } \\
\text { mix of self-reported and measured } \\
\text { data }\end{array}$ & 13.4 & 16.6 & 21.0 & 8.1 & 11.0 & 17.6 \\
\hline
\end{tabular}

\footnotetext{
${ }^{1}$ Important recent contributions to the literature on the Nordic countries include Iversen (2011) and Magnussen et al. (2009), as well as several contributions from the EuroHope project (Health Economics 24, Suppl. 2).

${ }^{2}$ For largely obscure reasons, however, the incidence of type 1 diabetes is four times higher in Finland and three times higher in Sweden than the OECD average. Norway has the third highest incidence.
} 
The rest of this paper is structured as follows. First, we argue that a full description of a health care system must include its institutional and social context (section 1). Then, we present the context in which Nordic health care operates (section 2). In section 3, we discuss the similarities (in particular) and differences across the Nordic countries in the organization and financing of health care. Section 4 tentatively looks into the future.

\section{The embeddedness of health care systems}

In his thought-provoking book Strained Mercy: The Economics of Canadian Health Care (1984), Bob Evans makes the important observation that studies that examine only one part of the health care market may have little to offer the policy maker. Problems of market failure and the process of institutional evolutions are an interactive totality (p. 94). Both aspects must be considered if we are to understand what occurs in the health care sector. We believe that this argument can be extended - health care does not exist in a vacuum but interacts with other parts of society.

To set the stage for health policy, we first briefly describe some of the most important features in the institutional and social context in which a health care system operates. Institutions are the rules of the game in a society, rules that shape human interaction (North 1981, 1990). Institutions can be both formal (laws, regulations) and informal (social norms). The institutional context has a great impact on the manner in which the health care system works. An efficient health care system in one institutional context need not be efficient in a different context. The performance of health care systems across the globe thus depends on the institutional structure in different countries, in which the health care sector is embedded. ${ }^{3}$

A health care system should consequently not be viewed in isolation and when we describe a health care system, we should include the institutional context (Lyttkens, 2015). In the remainder of this section, some of the more obvious dimensions of embeddedness will be noted.

Health care system governance can be based in private markets or political mechanisms or both. The Nordic health care system is an example in which political organizations provide governance. The chosen set of rules for political activity will influence outcomes in terms of public policy; for example, the choice between direct democracy and parliamentary democracy or whether it is possible to run deficits in public budgets in election years will influence the resource allocation in society. The long-term experience of democratic rule is also important. Trust facilitates democratic rule, and longterm democratic experience may breed trust.

In the private production of health care, outcomes will depend on the degree to which anti-trust policies and similar measures are pursued. Similarly, the manner in which the health authorities act when they negotiate and contract with private producers is important. Their actions will depend on the government regulation of public agencies and whether they are required to promote competition. For example, the EU-rules on outsourcing together with the Swedish law on public procurement establishes a set of rules that must be followed when a public entity purchases anything costly, such as MRI equipment. ${ }^{4}$

With regard to financing, what the heath sector can do (or cannot do) is very much a function of the extent to which other public activities rely on taxation to finance their

\footnotetext{
${ }^{3}$ A pragmatic aspect of the institutional context of the health care sector is that the definition of the health care sector differs across countries and so does, for example, the demarcation between health care and elderly care. ${ }^{4}$ Medical malpractice and liability play very different roles in different health care systems, depending in part on the differences between common and statutory law. The very different cases of the US and Sweden have been studied by Danzon (1994).
} 
activities. Using taxes to finance health care is clearly a very different matter when other public activities require tax revenues corresponding to 30 per cent of GDP or just 5 per cent. The deadweight losses of taxation and marginal social cost of public funds will vary accordingly (Hansson and Stuart, 1987) and hence also the social cost of public health care.

The structure of social norms and other informal rules are of fundamental importance. These include the high trust that characterizes the Nordic countries (see below), just as the absence of corruption. There is most likely a strong connection between intrinsic motivation and trust. The work ethos in the Swedish labour market has surprised many commentators and intrinsic motivation seems persuasive. The Nordic hospital-based physician, paid by salary, does not generally pursue effort-minimizing strategies. It also matters a lot whether the stipulated co-payments is the only pay the patient has to face or whether there is corruption.

Institutions determine transaction costs, which are important for the running of a business, whether it is a full-size acute care hospital or a private practice. These costs depend not only on public regulations but also on the security of property rights, the rule of law, and other aspects of economic freedom.

In summary, a health care system is not adequately described unless we also describe the context in which it operates. The health care system is embedded in a set of formal and informal institutions, in laws and in social values and norms of behaviour. The functioning of a particular organizational feature in a health care system will depend on this structure within which health care is embedded.

\section{The Nordic health care system in context: the institutional structure and the welfare state}

\subsection{The Nordic countries - similar yet different}

The Nordic countries are generally regarded as very similar. When the OECD began classifying health care systems, the Nordic countries were all placed in the same group. The Nordic countries are all small open economies, sparsely populated, with long traditions of democratic rule. Even Denmark, by far the most densely populated of the Nordic countries with a concentration of inhabitants in the Copenhagen area, has a greater segment of the population living in remote rural areas than the OECD average (Table 2).

The fact that Nordic countries are small open economies implies a lower bound for the return to capital. It also limits the possibilities for a monopsonistic public employer to manipulate wages; the Nordic countries have a joint labour market that facilitates movement across national borders for doctors, nurses, etc. It is regarded as a basic right for citizens in the Nordic countries to be able to freely seek employment in another Nordic country.

The Nordic countries have a considerable amount of common history, viz.: Iceland was part of Denmark for 850 years (independent since 1944); Norway was also part of Denmark for 700 years, and then part of Sweden for another 100 years (independent since 1905); Finland was part of Sweden for 700 years and then part of Russia for 100 years (independent since 1917). The inhabitants of the Nordic countries sometimes understand each other's language without translation (in particular Norway-Sweden). A number of organizations and international agreements have been created to facilitate cooperation across the Nordic countries (e.g., the Nordic Council, the Nordic Research Council, the Nordic passport union, the Common Nordic labour market, etc.). ${ }^{5}$

\footnotetext{
${ }^{5}$ However, there are problems. For example, it has proven very difficult to find a political solution to the many economic and institutional barriers that exist between Southern Sweden and Denmark, despite the fact that the two regions have been physically connected by a bridge since 2000 .
} 
Table 2: $\quad$ The Nordic Health care systems in context

\begin{tabular}{|c|c|c|c|c|c|c|}
\hline & Denmark & Finland & Iceland & Norway & Sweden & $\begin{array}{l}\text { OECD } \\
\text { average }\end{array}$ \\
\hline $\begin{array}{l}\text { Globalization, KOF-index, } 2012 \\
\text { (Dreher, 2006; Dreher et al., 2008) }\end{array}$ & 87.3 & 85.7 & 68.3 & 82.6 & 87.3 & 80.5 \\
\hline $\begin{array}{l}\text { Democracy, Polity IV index, } 2012 \\
\text { (Marshall et al., 2014) }\end{array}$ & 10 & 10 & N.A. & 10 & 10 & 10 \\
\hline $\begin{array}{l}\text { Democratic capital, } 1999 \text { (Persson } \\
\& \text { Tabellini, 2009) }\end{array}$ & 0.99 & 0.99 & 0.97 & 0.99 & 0.99 & 0.82 \\
\hline $\begin{array}{l}\% \text { living in "predominately remote } \\
\text { rural areas", 2011, } 25 \text { (OECD, } \\
\text { 2013b) }\end{array}$ & 18.8 & 18.7 & N.A. & 43.6 & 18.9 & 5.6 \\
\hline $\begin{array}{l}\text { Inhabitants per square kilometres } \\
\text { 2010, (UN, 2012) }\end{array}$ & 128.8 & 15.9 & 3.1 & 12.7 & 20.9 & 128 \\
\hline $\begin{array}{l}\% \text { high trust in others, } 2008^{*} \\
(\mathrm{OECD}, 2011)\end{array}$ & 89 & 86 & N.A. & 88 & 84 & 59 \\
\hline $\begin{array}{l}\text { \% confidence in government, } 2012 \\
\text { (OECD, 2014a) }\end{array}$ & 55.4 & 62.0 & $27.9 * *$ & 71.1 & 65.3 & 42.6 \\
\hline $\begin{array}{l}\text { Corruption index ICRG (1-6) } \\
\text { (ICRG, 2012) }\end{array}$ & 5.5 & 5.5 & 5.0 & 5.5 & 5.5 & 4.1 \\
\hline $\begin{array}{l}\text { GDP per capita, USD, } 2011 \\
\text { (OECD, 2014b) }\end{array}$ & 41,843 & 38,611 & 38,224 & 61,897 & 41,761 & 35,919 \\
\hline $\begin{array}{l}\text { Gini-coefficient (disposable income, } \\
\text { post taxes and transfers), } 2012 \\
(\mathrm{OECD}, 2015)\end{array}$ & 0.25 & 0.26 & 0.26 & 0.25 & 0.27 & 0.31 \\
\hline $\begin{array}{l}\text { Total general government revenue } \\
\text { as share of GDP, } 2011 \text { (OECD, } \\
\text { 2014b) }\end{array}$ & 55.9 & 54.3 & 41.8 & 57.6 & 51.5 & 41.9 \\
\hline
\end{tabular}

A very important feature of the Nordic countries is that there is a high degree of trust among the citizens. The Nordic countries are those where people are most prone to answer "yes" to the question "Generally speaking, would you say that most people can be trusted or that you need to be very careful in dealing with people?" In the Nordic countries, some $84-89 \%$ of the population believe that you can trust others (Table 2). The OECD average is $59 \%$. Trust have received a lot of attention lately. The Nordic countries have a number of characteristics that tend to increase generalized trust (Bjørnskov, 2006): they score relatively low on ethnic, linguistic and religious fractionalization (Patsiurko et al., 2012), inequality of income is low (cf. below), they are mainly protestant and three of them are monarchies.

Similarly, Nordic citizens display a comparatively high level of trust in their government. Four of the Nordic countries were among the top nine in the OECD with regard to trust in the government. ${ }^{6}$ The understandable exception is the Icelanders after their banking crises. Finally, we note a virtual absence of corruption in both the public sector and the private sector. ${ }^{7}$

\footnotetext{
${ }^{6}$ OECD (2014a), p. 139.

${ }^{7}$ Trust is also important for the absence of corruption (Bjørnskov and Svendsen, 2013).
} 
It is worth reminding ourselves that the establishment of the national states in Northern Europe in the $20^{\text {th }}$ century was comparatively peaceful. In 1905, the Norwegians voted for independence from Sweden, which was achieved without blood-shed. In 1921, the decision on the nationality of the archipelago of Aland was reached without violence. In 1944, Iceland became independent of Denmark. ${ }^{8}$ This compares favourably with many other state formation processes in history (lately, for instance, the Balkans in the $20^{\text {th }}$ century; the USA, Italy, and Germany, in the $19^{\text {th }}$ century and many others). We may add that the royal families in Denmark, Norway and Sweden are closely related to each other through marriages, etc. (but such marriage relationships did not prevent the Germans and the British from ending up on different sides in the First World War).

There are several institutional and other factors that separate the Nordic countries from the other OECD members. However, it is also easy to observe that there are important differences among the Nordic countries. For instance, of the five Nordic countries, only three are members of the European Union (Denmark, Finland, and Sweden), and only Finland has adopted the euro. Of the five, three are members of NATO (Denmark, Iceland, and Norway). ${ }^{9}$ Three Nordic countries are monarchies, whereas two elect presidents. Denmark, Norway and Sweden jointly own the SAS airline. Norway has struck oil and is now by far the richest of the Nordic countries.

This situation is mirrored in the health care sector, where we observe fundamental similarities but also some important differences. As discussed in the aforementioned report by the OECD, there are a number of significant differences in practical health care policy across the Nordic countries, (section 3.6 below).

\subsection{Beveridge and Bismarck}

All Nordic countries view themselves as welfare states, although the actual application of the model varies between countries and over time. Welfare states can take many forms and to a varying degree rely on the public sector or the market, family or civil society. Trusting populations are more likely to sustain large universal welfare states (Bergh and Bjørnskov, 2011).

Archetypical models of welfare states are the Bismarck model and the Beveridge models (Petersen, 2004). The distinguishing features of the Bismarck model are that it is based on social insurance principles (payment of insurance premiums supplemented with state grants and benefits depending on contribution). By contrast, the Beveridge model is based on taxation and benefits depending on need. With taxes instead of insurance premiums, the model is often labelled a social security model rather than a social insurance system as payments vary with income instead of health-risk. Most of the Nordic welfare states seem closest to the Beveridge model (Petersen 2004, p. 65), and this is also the case with regard to health care. In Finland, however, social insurance plays a significant role (cf. section 3.6).

The Swedish welfare state is often likened to a bumble bee. Theoretically, the bumble bee ought not to be able to fly, but it does so anyway in happy ignorance of the fact that it is doing the impossible. Similarly, the Nordic welfare state, with its relatively strong economic disincentives to work and distortionary taxation, ought to founder in the long

\footnotetext{
${ }^{8}$ In Finland however a civil war broke out in 1918, shortly after independence. This makes the high level of trust particularly noteworthy.

${ }^{9}$ Current policy still likely reflects the experiences from the Second World War, when Finland was attacked by the Soviet Union (which later annexed the Baltic states), Denmark and Norway were occupied by Germany, and Iceland was occupied by the British (later replaced by the Americans).
} 
term. However, the Nordic welfare states continue to thrive, sometimes reforming themselves but also retaining their fundamental characteristics, paying for health care, handing out sickness benefits, unemployment benefits, etc. In part, it survives by reforming itself. The median voter possibly believes that the welfare state is the same as it was 40 or 20 years ago, but the truth is that there has been dramatic change. ${ }^{10}$ Regardless, it seems fair to say that the term "welfare state" has a very positive connotation in the Nordic countries. ${ }^{11}$

A current trend in health care policy is that of deregulation - increasing the scope for private entrepreneurs in health care. We view this trend as a reflection of the international trend in recent decades towards an increase in economic freedom in many walks of life (Table 3). This tendency has been even more pronounced in several of the Nordic countries. Over the 1980-2010 period, the absolute increase in the economic freedom index in Iceland, Norway and Sweden was larger than the global average increase. In Denmark and Finland, the absolute increase was smaller than the global average, but these two countries started from much higher index levels. In 2010 the value of the index was higher than the global average in all of the Nordic countries.

\section{Table 3: The Nordic countries in the Economic Freedom Index*}

\begin{tabular}{lllllll}
\hline & & & & & $\begin{array}{l}\text { Change } \\
1980-2010\end{array}$ & $\begin{array}{l}\text { Change } \\
2000-2010\end{array}$ \\
\hline Year & 1980 & 1990 & 2000 & 2010 & & \\
\hline Denmark & $6.39(20)$ & $7.26(16)$ & $7.92(13)$ & $7.76(16)$ & 1.37 & -0.16 \\
Finland & $6.65(15)$ & $7.24(17)$ & $7.73(17)$ & $7.89(9)$ & 1.24 & +0.16 \\
Iceland & $5.25(54)$ & $6.95(24)$ & $8.04(11)$ & $7.02(65)$ & 1.77 & -1.02 \\
Norway & $5.79(32)$ & $7.13(19)$ & $7.27(40)$ & $7.53(25)$ & 1.74 & +0.26 \\
Sweden & $5.68(37)$ & $7.11(21)$ & $7.62(19)$ & $7.62(30)$ & 1.94 & $+/-0$ \\
Global average** & 5.30 & 5.76 & 6.71 & 6.83 & 1.53 & 0.12
\end{tabular}

Source: Gartner, Lawson and Norton (2013), Ch. 1-2.

* In parenthesis, rank among countries for which there are figures dating back to 1980.

** Average for countries for which there are figures dating back to 1980.

The reduction in economic freedom in Iceland since 2000 is due to the economic crises of 2008-2011 (the index fell from 8.09 in 2005 to 7.20 in 2009). Indeed, in 2000, prior to the crisis, Iceland surpassed the other Nordic countries in economic freedom. Iceland now seems to be on the mend and the economic freedom index increased substantially in 2011.

Several of the specific characteristics of the health care system in the Nordic countries follow naturally from the connection with the welfare state. An integral part of the welfare state and a very important objective is to ensure easy and equal access to adequate health care for the entire population.

Not only is health care largely tax-financed but the Nordic countries are found among the high-tax societies. In 2012, total tax as share of GDP was above $40 \%$ in eight OECD countries; four of these were Nordic, with Denmark as the overall highest share of

\footnotetext{
${ }^{10}$ For Sweden, this process is nicely described by Bergh and Erlingsson (2008). Private entrepreneurs are now active in nursing home care and primary care, the pension system has been changed so that benefits are now determined by contributions, etc.

${ }^{11}$ For example, a positive attitude is expressed in an old popular Danish poem that says (translated) "...we have reached far in wealth when few have too much and fewer too little" (Grundtvig, 1820).
} 
taxes with $48 \% .^{12}$ Simultaneously, the Gini-coefficients in the Nordic countries are small compared to the OECD (although they have increased substantially for more than a decade, a development driven mainly by the top incomes in society); see Table 2 . Illegal tax evasion is not seen as a big problem in the Nordic countries, which suggests that quasi-voluntary compliance is important (see below), as is the high degree of trust. ${ }^{13}$

\subsection{Implications for the provision of health care in the Nordic countries}

The characteristics of the Nordic countries described in sections 2.1-2 must reasonably have a major impact on the functioning of the health care system. For example, it seems likely that we are in a situation in which employees in the health care sector strive to do their best at work (expend effort), provided that they believe (trust) that others do the same. In this manner intrinsic motivation can be sustained by trust. We have borrowed this insight from the area of taxation, where it is encapsulated in the concept of quasi-voluntary compliance (Levi, 1988). The idea is that people will sometimes pay their taxes, even when the probability of detection is low. This can occur when people believe both that they get something valuable for their taxes and that others are also paying their taxes.

A high level of trust will generally be conducive to a more efficient production of health (and most other gods and services). When decision makers trust each other, transaction costs will be lower, and the production of health care will be cheaper. With trust, it is likely that quality will be higher and costs will be lower. Similarly, the absence of corruption leads to a more efficient production of health care.

These institutional similarities constitute our most important reason for conceptualizing a Nordic health care system. Our approach differs from the recent OECD study noted above at the beginning (Joumard et al., 2010), where classification of health care systems is based on econometric analyses. Using principal component analysis, the OECD exercise leads to a categorization into six groups, with the five Nordic countries ending up in three different groups, but all under the overall heading "mostly public provision and public insurance." Although the OECD approach brings new insights to this area, it is essentially based on the differences across nations. We believe that our approach, based on similarities in institutional context, is valid for many purposes. ${ }^{14}$ The Nordic countries share so many features that it seems less suitable to place them in different groups. Similar to large parts of the literature, the OECD studies on the classification of health care systems tend to ignore the overall institutional structure of society.

\footnotetext{
12 The marginal tax wedge is correspondingly substantial. In Sweden, for example, the top marginal tax in the income tax is just below $60 \%$, the payroll tax is $31 \%$, and the VAT is $25 \%$.

${ }^{13}$ Several studies have documented positive correlations between survey measures of institutional quality, trust in government, and satisfaction with public services and survey measures of tax morality (OECD, 2013c), see also Luttmer and Singhal (2014) and Torgler (2005). Tax moral can be defined as the intrinsic motivation to pay taxes (Alm and Torgler, 2004).

14 The classification of a country is always a hazardous undertaking, and the new OECD classification of Sweden seems to be based on a misunderstanding. Joumard et al. (2010) argue that, in Sweden, individual patients have extensive possibilities to choose their health care provider. This is most likely based on the absence of gatekeeping in Sweden. In itself, this is correct. Compared to other tax-financed systems, Sweden has little gatekeeping; thus, you can go directly to a hospital specialist (similar to social insurance countries such as France or Germany). It is also possible to choose a primary care centre and a hospital for outpatient care. However, it is also the case that, in Sweden, the individual cannot choose a particular surgeon at a hospital or in many cases choose a particular GP (Anell et al., 2012). The county councils also appear reluctant to allow their citizens to seek care elsewhere. Patients can take the initiative to seek care abroad, and this practice is increasing. In 2012, the figure for Sweden had risen to approximately 4500 cases per year, from approximately 1200 in 2009 . Denmark is the leading provider, with more than $50 \%$ of these cases, and overall, the possibility is utilized primarily by people in Skåne, the Stockholm area and the very north of Sweden (Anell, 2014), in other words, those living close to other countries.
} 
We believe that the first and foremost characteristic of the Nordic health care system is the particular context in which it operates. The Nordic health care system should thus be conceived as a health care sector that is embedded in a high-trust and high-taxation society.

A related issue is that, when we discuss a health care system, we normally only consider formal rules. However, informal rules are equally important in society and may counteract the formal rules (North, 1990). For example, a social norm that you should work hard can counteract the lack of any obvious financial incentives to work hard or to be efficient. This phenomenon may be particularly important for salaried doctors whose behaviour is difficult to monitor and who work in an environment that encourages altruistic behaviour but sometimes also provides "perverse" financial incentives.

In view of the contextual similarities, it is not surprising that there remain today several important similarities in health care across the Nordic countries, similarities that are sufficiently important to constitute our second reason for using the term "the Nordic health care system." Some of these similarities seem to be the logical consequences of the similarities in the institutional context.

\section{A closer look at the health care sector in the Nordic countries}

\subsection{Uncertainty and insurance}

We have now come to the ways in which health care is organized and financed in the Nordic countries and we observe some significant commonalities. In his seminal article, Arrow (1963) suggests that all of the peculiarities we encounter in the medical care market essentially have their origin in uncertainty regarding the incidence of disease and the efficacy and long-term consequences of medical treatment. As frequently noted, consumers find it difficult to judge quality of care not only before the treatment but also after the treatment. There is uncertainty with respect to one's future health care needs and regarding the optimal size of health care expenditure. To this we can add the increasingly high cost associated with new treatment methods. The implication is that insurance against the future costs of health care (and against loss of income in case of illness) is likely to be welfare improving. For the remainder of this paper, health insurance will be taken to mean health care insurance (insurance against loss of income will not be discussed further).

Arrow (1963) also notes that there will not necessarily be a market for all health risks or in all geographical areas. Indeed, some patient groups (the chronically ill, the poor and the destitute, etc.) will find it difficult to find affordable insurance. Furthermore, some markets may be too small to be viable. Thus, health insurance need not be forthcoming in remote regions with a low population density (Tinghög et al., 2010).

All high-income societies seem to have reached the conclusion that some government intervention in the market for health insurance is warranted and that this intervention also entails some subsidies to the consumption of health care. The five Nordic countries have all chosen to tax-finance health care. This seems like a logical conclusion from the problems described above, in combination with the contextual fact that the countries are sparsely populated, and the notion of a welfare state. The situation is equivalent to covering the population with an implicit compulsory health insurance with undifferentiated premiums (contributions vary with income).

The Nordic countries are all dedicated to the principle of equality of access for the entire population, a reflection of the universality of the welfare state. It combines two goals: everybody is assured health care for the future and there is equal access to health care. Equality of access can be viewed as a reflection of what Tony Culyer (1980) designated "a caring externality". The idea is that we may feel good if we know that our fellow citizens 
receive the care they need. In a European setting, such arguments seem to carry more weight than Arrow anticipated. The Nordic countries are exceptional in that they view the individual as the proper unit of analysis for distributional issues. Most other countries focus instead on the family or the household as the unit of analysis (Trägårdh, 2015).

Statements regarding equality of access can be found in the legislation of all the Nordic countries (as in many others). There seems to be a genuine commitment to this principle in the Nordic countries, and this is arguably a distinguishing feature of the Nordic health care systems. However, the outcome in terms of income-related inequalities in the consumption of health care is another matter. ${ }^{15}$

\subsection{Moral hazard - restraining the patient's health care consumption}

Irrespective of the precise nature of health insurance, the low costs to the patient at the point of consumption create a risk of moral hazard effects. The need to restrain consumption is emphasized by the emergence of ever more expensive medical technologies. Cost sharing on the demand side (patients' co-payments) cannot, however, be used extensively to restrain demand without defeating the original purpose of the public subsidies, namely to make consumption choices independent of financial considerations. Consumption must therefore be constrained from the supply side.

All high-income countries restrain patients' demand to some extent, but the method varies across countries. All of the Nordic countries have chosen to rely on combinations of waiting time, prioritization among patients undertaken by the health care provider organization, and finally, rationing at the point of consumption. ${ }^{16}$ The countries differ, however, with respect to which actor undertakes this prioritization. ${ }^{17}$ For example, Denmark uses primary care physicians to act as gatekeepers, whereas in Sweden, there is no formal gatekeeper, and rationing often occurs somewhere inside hospital organizations. ${ }^{18}$

\subsection{Quality of health care and the incentives of providers}

In the medical market, doctors not only provide treatment but also provide information. There are endless situations when the doctor has an informational advantage over the patient (and over any administrators). An important characteristic of a health care system is whether providers are given financial incentives to restrain health care consumption, whether the reimbursement system is neutral in this respect, or whether the provider can increase profits by providing more health care. DRG systems are to some extent used in the Nordic countries to remunerate hospitals or hospital departments, but the effect of this when combined with global budgets is difficult to disentangle.

Two of the outstanding characteristics of health care in the Nordic countries are public financing of health care and that inpatient care is provided by salaried doctors who work as public employees in public hospitals. This eliminates any financial incentives for the provider at this level to add to the tendency to overconsumption or to skimp on quality. This set-up encourages trust in providers. Strengthening the provider's incentive to reduce

\footnotetext{
${ }^{15}$ How policy translates into outcomes is a separate issue, and a system of public rationing and waiting times is not necessarily to the benefit of the less well-off (section 3.5 below). Van Doorslaer and Masseri (2006) found relatively high income-related inequality in doctor visits in Finland and Sweden.

${ }^{16}$ With respect to terminology, we use the label "prioritization" for budgeting decisions, whereas similar decisions at the bedside are referred to as "rationing".

${ }^{17}$ No decision maker wants to be seen as the one to make such decisions (Coast, 2001), and we expect that everybody attempts to pass the buck to someone else.

${ }^{18}$ The Swedish county councils attempt to use minor differences in patients' co-payments to guide the patients to the "correct" provider.
} 
costs can be problematic, given that costs can be reduced not only by increasing efficiency but also by reducing quality.

However, quality of care is also a function of the effort exerted by physicians (and other employees), and effort may negatively affect physician utility. A possible outcome could be that a publicly employed doctor strive to minimize effort but perhaps also to do a good job (intrinsic motivation). There are incentives to reduce quality (reduce effort), unless there are some rewards for effort, such as peer appreciation, or quality is monitored. ${ }^{19}$

We will now take a closer look at quality of care in the Nordic countries. However, let us first notice that, within the OECD, there are countries with widely different possibilities in terms of incomes (resources that could be spent on health care). For example, to note that the Nordic countries provide health care of a higher quality than the OECD average is only moderately interesting when we can observe that the Nordic countries also have incomes per capita that are well above the OECD average (Table 4). Consequently, we will compare health care quality in the Nordic countries with that in those OECD countries that are at the same income level as the Nordic countries. We focus our comparisons on those OECD countries that are poorer than Norway but richer than Iceland (the richest and poorest of the Nordic countries). Furthermore, we will focus on small European countries. ${ }^{20}$ These criteria leave us with a group of five OECD countries to compare the Nordic countries with, namely: Austria, Belgium, Ireland, the Netherlands and Switzerland. We will designate these countries the FCC (Five Country Comparison) group.

Table 4: Health care resources and financing, 2011*

\begin{tabular}{llllllll}
\hline & Denmark & Finland & Iceland & Norway & Sweden & $\begin{array}{l}\text { OECD } \\
\text { average }\end{array}$ & $\begin{array}{l}\text { FCC } \\
\text { average }\end{array}$ \\
\hline $\begin{array}{l}\text { Health expenditure per } \\
\text { capita, USD PPPs, 2011 }\end{array}$ & 4448 & 3374 & 3305 & 5669 & 3925 & 3322 & 4610 \\
$\begin{array}{l}\text { Health spending, } \\
\% \text { of GDP }\end{array}$ & 10.9 & 9.0 & 9.0 & 9.3 & 9.5 & 9.3 & 10.6 \\
$\begin{array}{l}\text { Financing, general } \\
\text { government, \% of current } \\
\text { expenditure }\end{array}$ & 85 & 60 & 51 & 73 & 82 & 35 & 27 \\
\end{tabular}

Source: OECD (2013a).

* Note that long-term care is reported differently by different countries; thus, these figures only provide a rough indication of the resources used.

FCC = Austria, Belgium, Ireland, the Netherlands, and Switzerland.

To gain some insight into quality of care in the Nordic countries, we have chosen a simple and straightforward set of quality indicators from the OECD Health at a glance 2013. Comparing such outcome measures seems reasonable, although it gives a less than clearcut ordering of the health care systems (Joumard et al., 2010). There are also inherent and inevitable difficulties in the interpretation of different quality indicators across countries. It is a notoriously unreliable method because of varying definitions, etc. Nevertheless, when used with great caution, the overall picture is arguably not without interest.

\footnotetext{
${ }^{19}$ In Denmark, for instance, quality indicators are available to peers, and quality is monitored.

${ }^{20}$ The Nordic countries also belong to those with WEIRD populations (western, educated, industrialised, rich, and democratic), countries that generally differ from other populations (Henrich et al., 2010).
} 
We use the following indicators (Tables 5A and 5B): a) Avoidable hospital admissions, measured as admission for asthma and COPD, i.e., hospital admissions for these reasons are taken to signify bad disease management; b) Acute exacerbations of chronic conditions, measured as case-fatality for adults 45+, within 30 days after admission for AMI or for ischemic stroke; ${ }^{21} \mathrm{c}$ ) Prevention, measured as the rates of childhood vaccinations and influenza vaccination for the elderly; d) Prescriptions of antibiotics (to be avoided); and e) Cancer mortality (cervical, breast, and colorectal).

Table 5A: Health care system quality indicators

\begin{tabular}{|c|c|c|c|c|c|c|}
\hline & Denmark & Finland & Iceland & Norway & Sweden & $\begin{array}{l}\text { FCC } \\
\text { average** }^{* *} \\
\text { (p-value) }\end{array}$ \\
\hline $\begin{array}{l}\text { Avoidable hospital admissions for } \\
\text { asthma, adults per } 100,000 \\
\text { residents, } 2011\end{array}$ & 36.3 & 67.8 & 40.7 & 28.1 & 22.2 & $\begin{array}{l}37.5 \\
(0.421)\end{array}$ \\
\hline $\begin{array}{l}\text { Avoidable hospital admissions for } \\
\text { COPD, adults per } 100,000 \\
\text { residents, } 2011\end{array}$ & 291.8 & 143.4 & 236.7 & 210.6 & 168.8 & $\begin{array}{l}231.8 \\
(0.421)\end{array}$ \\
\hline $\begin{array}{l}\text { AMI admissions, case fatality } \\
\text { within } 30 \text { days in adults aged } 45+\text {, } \\
\text { per } 100 \text { admissions, } 2011\end{array}$ & 3.0 & 7.0 & 5.7 & 4.5 & 4.5 & $\begin{array}{l}7.0 \\
(0.028)\end{array}$ \\
\hline $\begin{array}{l}\text { Stroke admissions, case fatality } \\
\text { within } 30 \text { days in adults aged } 45+\text {, } \\
\text { per } 100 \text { admissions, } 2011\end{array}$ & 4.1 & 5.4 & 7.0 & 5.3 & 6.4 & $\begin{array}{l}7.9 \\
(0.111)\end{array}$ \\
\hline $\begin{array}{l}\text { Childhood vaccinations (children } \\
\text { aged 1) DTP-Measles, } 2011\end{array}$ & $91-87$ & $99-97$ & $95-94$ & $94-93$ & $98-97$ & $\begin{array}{l}93.6- \\
90.4 \\
(0.345)\end{array}$ \\
\hline $\begin{array}{l}\text { Influenza vaccinations for elderly } \\
\text { people } 65+, 2011\end{array}$ & 45.6 & 38.5 & N.A. & 14.1 & 64.0 & $\begin{array}{l}55.5 \\
(0.345)\end{array}$ \\
\hline $\begin{array}{l}\text { Antibiotics prescribed, DDDs per } \\
1,000 \text { patients, per day, } 2010\end{array}$ & 16.5 & 18.5 & 22.2 & 15.8 & 14.2 & $\begin{array}{l}18.7 \\
(0.345)\end{array}$ \\
\hline $\begin{array}{l}\text { Cervical cancer mortality per } \\
100,000 \text { women, } 2011\end{array}$ & 2.3 & 1.4 & 1.2 & 2.5 & 2.5 & $\begin{array}{l}2.7 \\
(0.155)\end{array}$ \\
\hline $\begin{array}{l}\text { Breast cancer mortality per } \\
100,000 \text { women, } 2011\end{array}$ & 34.7 & 23.1 & 30.9 & 21.5 & 23.2 & $\begin{array}{l}30.6 \\
(0.155)\end{array}$ \\
\hline $\begin{array}{l}\text { Colorectal cancer mortality per } \\
100,000 \text { residents (age-std. rates), } \\
2011\end{array}$ & 31.0 & 17.5 & 20.5 & 29.6 & 22.6 & $\begin{array}{l}23.9 \\
(0.579)\end{array}$ \\
\hline
\end{tabular}

${ }^{21}$ A major caveat is that these statistics are often not based on complete patient treatment episodes, i.e., it is not possible to follow an individual patient. Hence, for example, the same patient may turn up several times in the material during the same episode. 
Table 5B: Health care system quality indicators

\begin{tabular}{|c|c|c|c|c|c|c|}
\hline & Austria & Belgium & Ireland & Netherlands & Switzerland & $\begin{array}{l}\text { FCC } \\
\text { average }\end{array}$ \\
\hline $\begin{array}{l}\text { Avoidable hospital } \\
\text { admissions for asthma, adults } \\
\text { per } 100,000 \text { residents, } 2011\end{array}$ & 50.6 & 37.9 & 36.8 & 31.8 & 30.2 & 37.5 \\
\hline $\begin{array}{l}\text { Avoidable hospital } \\
\text { admissions for COPD, adults } \\
\text { per 100,000 residents, } 2011\end{array}$ & 319.6 & 217.2 & 365.0 & 162.1 & 95.1 & 231.8 \\
\hline $\begin{array}{l}\text { AMI admissions, case fatality } \\
\text { within } 30 \text { days in adults aged } \\
45+\text {, per } 100 \text { admissions, } \\
2011\end{array}$ & 7.7 & 7.6 & 6.8 & 6.8 & 5.9 & 7.0 \\
\hline $\begin{array}{l}\text { Stroke admissions, case } \\
\text { fatality within } 30 \text { days in } \\
\text { adults aged } 45+\text {, per } 100 \\
\text { admissions, } 2011\end{array}$ & 6.0 & 9.2 & 9.9 & 7.5 & 7.0 & 7.9 \\
\hline $\begin{array}{l}\text { Childhood vaccinations } \\
\text { (children aged 1) DTP- } \\
\text { Measles, } 2011\end{array}$ & $83-76$ & 98-96 & 95-92 & $97-96$ & 95-92 & $\begin{array}{l}93.6- \\
90.4\end{array}$ \\
\hline $\begin{array}{l}\text { Influenza vaccinations for } \\
\text { elderly people } 65+, 2011\end{array}$ & 36.1 & 65.0 & 56.3 & 74.0 & 46.0 & 55.5 \\
\hline $\begin{array}{l}\text { Antibiotics prescribed, DDDs } \\
\text { per 1,000 patients, per day, } \\
2010\end{array}$ & 15.0 & 28.4 & 20.3 & 11.2 & N.A. & 18.7 \\
\hline $\begin{array}{l}\text { Cervical cancer mortality per } \\
100,000 \text { women, } 2011\end{array}$ & 2.9 & 3.1 & 4.3 & 2.0 & 1.3 & 2.7 \\
\hline $\begin{array}{l}\text { Breast cancer mortality per } \\
100,000 \text { women, } 2011\end{array}$ & 26.0 & 34.2 & 31.6 & 32.8 & 28.3 & 30.6 \\
\hline $\begin{array}{l}\text { Colorectal cancer mortality } \\
\text { per 100,000 residents (age- } \\
\text { std. rates), } 2011\end{array}$ & 21.8 & 24.2 & 25.8 & 28.5 & 19.1 & 23.9 \\
\hline
\end{tabular}

An overall impression from these two tables is that the Nordic countries do not provide low-quality health care compared to the FCC group, rather the opposite, and they show slightly lower overall costs (see Table 4 above). In some cases, as a group, the Nordic countries seem to have performed better than the FCC group, indeed significantly better in the case of AMI $(p=0.03)$ and nearly significantly better in the case of stroke $(p=0.11$, rank sum test). We should note that there is considerable variation between the countries within each group. For example, Switzerland scores relatively high on quality (it outperforms, e.g., Denmark) but does so at a relatively high cost in terms of expenditure per capita. Comparing Norway with Switzerland, two countries that are similar in health care expenditure per capita (5669 vs. 5643) and mountains, shows Norway on top with regard to almost all indicators.

\subsection{Increasing returns to scale?}

A 'market failure' type of problem in the health sector is the potential presence of increasing returns (Arrow, 1963). The unregulated market will converge towards oligopoly or 
monopsony. Increasing returns are very likely to be a problem in hospital care in small communities in the Nordic countries.

The Nordic countries have all largely opted for public acute care hospitals. This choice is a reasonable decision, given that the sparsely inhabited parts of the countries would otherwise have ended up with private (natural) monopolies and/or opportunistic public buyers of health care (see Williamson, 1985).

The experience of the UK has suggested that, in a quasi-market, increased competition can, under certain circumstances, lead to increased quality without increasing costs (Gaynor et al., 2010). However, this proposition does not seem to hold generally (Feng et al., 2014; Gravelle et al., 2012). Somewhat similarly, private competitive markets in the US seem to reduce costs without sacrificing quality. Viewed in this light, the Nordic countries are potentially at a disadvantage compared to countries where a competitive market or quasi-market can be established. This situation would only be possible in some particularly densely populated Nordic regions such as greater Copenhagen in combination with the south of Sweden.

\subsection{Waiting times}

There remains one important aspect of health care quality, and that is waiting times. Health care is typically rationed with queues/waiting time in publicly financed health care systems. This practice has two implications. First, access to health care is less than it might appear at first glance. The longer the waiting time is, the lower the quality of care because the benefits of treatment are typically presumed to decrease with waiting (Gravelle et al., 2003; Propper, 1995). Longer waiting implies fewer benefits from the health care received (notably cancer treatment) and pain and suffering when waiting. With long waiting times, some patients will die, and others will turn to private care or drop out of the queue for other reasons. There are indications that the elasticity of utilization with respect to waiting time is low (Martin and Smith, 2003).

Furthermore, waiting lists introduce differences across the population in terms of access to treatment. It may well be that high-income individuals have greater possibilities to navigate in a landscape of health care queues (Tinghög et al., 2014).

Unfortunately, good data on waiting times are rare and cross-country comparisons very difficult (Siciliani et al., 2014). As a very imprecise indicator, we can examine utilization rates. If waiting times severely reduce utilization, then their long-term impact ought to be reflected in utilization rates. However, hip and knee replacement ratios seem to be somewhat similar among the Nordic countries and in the FCC group (Table 7). There is no obvious rationing of Nordic patients revealed by these aggregate measures (however, the figures indicate that several factors could be at work $^{22}$ ).

All of the Nordic countries except Iceland have "health care guarantee" regulations concerning waiting times. However, these regulations do not need to be binding, and there can be separate time periods for: a) getting in contact with the provider organization; $b$ ) being met by a GP; c) being met by a specialist; d) being sent with a referral to a hospital and e) being diagnosed; and f) (finally) receiving treatment. In Sweden, these different waiting periods can add up to more than 6 months of waiting. In Finland, there was a reduction in waiting times following the introduction of a National Health Care Guarantee introduced into Finnish law in 2005. For an elective treatment, the guarantee was three

${ }^{22}$ For example, in the FCC group, we find almost the same rank order between the five countries for the two procedures $(\mathrm{CH}, \mathrm{A}, \mathrm{B}, \mathrm{NL}$ IRL vs. A, $\mathrm{CH}, \mathrm{B}, \mathrm{NL}, \mathrm{IRL})$. No such regularity is observable among the Nordic countries. 
months (with a few exceptions). Hospitals that failed to comply with the guarantee were scrutinized by the Supervisory Agency and were subject to a threat of penalty fines.

Finally, the fact that private health insurance is spreading in the Nordic countries (Alexandersen et al., this issue) is a reasonably clear sign that waiting times are viewed as problematic from the demand side, as is the fact that some patients go abroad for treatment.

Table 6: Indicators of exceptional circumstances in the Nordic countries

\begin{tabular}{llllllll}
\hline & Denmark & Finland & Iceland & Norway & Sweden & $\begin{array}{l}\text { OECD } \\
\text { average }\end{array}$ & $\begin{array}{l}\text { FCC } \\
\text { average }\end{array}$ \\
\hline $\begin{array}{l}\text { Infant mortality rates } \\
\text { per } 1000 \text { live births, }\end{array}$ & 3.6 & 2.4 & 1.6 & 2.4 & 2.1 & 4.1 & 3.6 \\
$\begin{array}{l}2011 \\
\text { Caesarean section rates } \\
\text { per } 100 \text { live births, }\end{array}$ & 21.2 & 16.2 & 14.7 & 16.5 & 16.2 & 26.9 & 24.7 \\
$\begin{array}{l}2011 \\
\text { Consultations per } \\
\text { doctor (estimated), } \\
\text { 2011 }\end{array}$ & 1.3 & 1.3 & 1.7 & 1.3 & 0.8 & 2.4 & 1.7 \\
\hline Source: OECD (2013a) & & & & & & & \\
\hline
\end{tabular}

Table 7: Utilization rates for hip and knee replacements in Nordic countries (upper row) and in FCC countries (lower row)

\begin{tabular}{|c|c|c|c|c|c|c|c|c|c|c|}
\hline Utilization rates: & & & & & & & & & & \\
\hline Nordic & & & $\mathrm{N}$ & $\mathrm{S}$ & & DK & SF & & ISL & \\
\hline FCC & $\mathrm{CH}$ & A & & & B & & & NL & & IRL \\
\hline $\begin{array}{l}\text { Hip replacement surgery rates per } \\
100,000 \text { residents, } 2011\end{array}$ & 306 & 273 & 242 & 238 & 236 & 225 & 225 & 216 & 173 & 118 \\
\hline $\begin{array}{l}\text { Knee replacement surgery rates per } \\
100000 \text { residents, } 2011\end{array}$ & 205 & 218 & 84 & 128 & 178 & 175 & 193 & 118 & 91 & 40 \\
\hline
\end{tabular}

Source: OECD (2013a)

\subsection{The Nordic health care system}

In view of the discussion above, the list of important similarities among the Nordic health care systems can be summarized as follows:

- The emphasis in public policy is on equal and easy access to high-quality health care. For example, education, income, etc. should have no effect, ceteris paribus, on health care ${ }^{\mathrm{i}}$ consumption.

- The main system of governance is one of public administration (hierarchies rather than markets), subject to political decisions by locally elected bodies with the power to tax (Magnussen et al., 2009).

- Health care is provided as a social security measure, and the system covers the entire population.

- The system is financed by taxation (but various co-payments exists). 
- Almost all acute care hospitals are public, and the physicians who work in them are salaried. A few private hospitals and clinics serve as a complementary capacity and as safety valves.

- The health care sector is decentralized, but the nature of decentralization differs across the Nordic countries (Iversen et al., this issue)

Finland represents a somewhat special case because primary health care consists of three systems segmented by socio-economic groups: i) public municipal services (health centres) that presently provide services mainly for non-active persons (children, the elderly, the unemployed); ii) occupational care services (producers, mainly private firms) that provide primary health care services for the active (working) population, financed by employers and the Social Insurance Institution; and iii) private doctors' services (reimbursed in part by the Social Insurance Institution and including care by both specialists and non-specialists (some of whom work part-time and have permanent positions in the public sector). The use of these private doctor services is very popular among children covered by voluntary private insurance.

Nevertheless, the similarities across the Nordic countries seem larger than, e.g., across the southern European countries, which likewise have been argued to represent a particular type of health care system (Toth, 2010).

Turning to the major differences across the Nordic countries, we note that primary care physicians are mostly private practitioners in Denmark, Iceland and Norway, while there is more of a 50/50 split between private/public practitioners in Finland and Sweden (where the proportion of private practitioner is on the increase). General practice represents differences between the Nordic countries not only in terms of public vs. private provision but also in terms of whether the GP functions as gatekeeper to inpatient and/or specialist care. GPs are gatekeepers in Denmark but not in Sweden. In Sweden, one can contact an inpatient or outpatient specialist without first consulting with a GP. Primary care in the Nordic countries is described in Rose Olsen et al. (this issue).

Another area of conspicuous differences is the nature of decentralization and division of responsibilities among various public entities (Iversen et al., this issue). The taxtreatment of private health insurance varies considerably across the Nordic countries (Alexandersen et al., this issue). The similarities and differences in the hospital sector in the Nordic countries have been the object of several recent studies and are not discussed in detail here (see, for instance, Kittelsen et al. 2015; Medin et al., 2013).

Administrative costs are likely to be low in systems such as those in the Nordic countries. Joumard et al. (2010, p. 23) report that administrative costs were less than $2 \%$ of current expenditures in Norway and Denmark whereas they were $7 \%$ in many other countries.

Finally, there are some areas where the Nordic countries stand out compared to the general OECD picture (Table 6). We note very low infant mortality in the Nordic countries and very low rates of Caesarean sections. Whether this has anything to do with, for example, the fact that the gender gaps for privileged positions in private and public life are comparatively small in the Nordic countries, we leave as an issue for future research.

The Nordic public system also allows seemingly strange/idiosyncratic customs to develop. The Nordic countries rank at the bottom with regard to consultations per doctor: the OECD reports figures for 32 countries, and in this group, the Nordic countries rank $22^{\text {nd }}$, $27^{\text {th }}, 28^{\text {th }}, 29^{\text {th }}$, and $32^{\text {nd }}$. Note that a contributory factor here can be the high marginal rates of income taxation, which reduce the incentive for doctors to work long hours or indeed to enter private practice and even the medical profession itself. 


\section{Some reflections on the future of the Nordic health care system(s)}

It is very difficult to predict the future, especially in light of the ubiquity of unforeseen consequences of purposeful actions (Merton, 1936; Weesie and Wippler, 1986). Therefore, we limit ourselves to reflecting on what seem to us to be some crucial issues for the future of the Nordic health care system and the Nordic welfare states. ${ }^{23}$

What seems certain is that new expensive medical technologies will continue to appear and this will continue to put upward pressure on health care expenditures. All realistic scenarios for the future seem to imply that incomes will come to play a greater role (Lyttkens, 2010). Incomes will matter more if nothing is done to reform the system because, in such a case, an increasing number of citizens will acquire private health insurance as waiting times increase. Eventually, some types of health care will likely be excluded from the public package or the cap on out-of-pocket expenditure will be raised. In the long run, this may erode the basis for the welfare state.

Historically, the constituting elements and content of the Nordic welfare states have always been challenged and modified in response. During the last two or three decades, each Nordic system has gradually been reformed through the introduction of the decentralization of responsibilities and elements borrowed from the market, known as "New Public Management" (Christiansen, 2014). Examples from the health care sector are the free patient choice of provider, the outsourcing of certain services, the decentralization of responsibilities, and the use of output measures such as Diagnosis Related Groups for the allocation of funds and for benchmarking hospital productivity and the introduction of economic incentives to increase production within the frame of a principal-agent model (Alban and Christiansen, 1995; Klausen and Ståhlberg, 1998; Häkkinen and Jonsson, 2009).

Traditionally, the Nordic welfare state has relied on strong public support and strong social coherence, but these characteristics are increasingly challenged by international mobility of labour and capital and globalization. Inevitably, this situation challenges a system based on national financing and, more broadly, it challenges the norms and values on which a national system is built (Petersen, 2004). This "social contract" entails a mutual understanding among citizens to contribute according to their ability and to receive help according to their need, and furthermore a mutual understanding among generations to contribute when at working age while receiving in childhood and when old. As the Nordic welfare states experience increasing income inequality, ethnic diversity, etc., the sustainability of this 'contract' is questionable.

We have argued that trust is likely one of the central features of the Nordic countries. A crucial question for the long term outlook is therefore the extent to which trust will remain high. Several of the factors positively associated with trust seem likely to be challenged by ethnic and religious fractionalization and social and economic polarization. ${ }^{24}$

A related issue will be the attitude towards new entrants in the market, such as doctors from non-Nordic countries. At present, Norway imports health care personnel from the other Nordic countries, whereas the latter import from other European countries.

\footnotetext{
${ }^{23}$ Recent trends have moved the five countries closer to a common solution. For example, the degree of decentralization used to vary considerably, but all five countries recently seemed to aim for decentralization with units of between 500000 to 1 million inhabitants. Iceland has a centralized health care system, but then the entire population of Iceland is no more than 323000 (in 2013). Finland appear forever undecided, and at the time of writing (February 2016), the aim is to centralise health care to 18 (or 15) counties.

${ }^{24}$ Historically, emigration between the Nordic countries have been important. For example, in 1960, of those inhabitants in Sweden that were born in another country, those born in Finland constituted $34 \%$ (58\% came from the four Nordic countries.
} 
Similarly, what will be the reaction to patients seeking care abroad? The free mobility within the common market may prove to be a challenge.

The health care systems in the five Nordic countries have shown remarkable resilience. ${ }^{25}$ There has been reform but also a continued insistence on some fundamental principles. Whether this will be a sustainable system for the future, however, is an open question. The future challenge is not to preserve the model as it stands today but rather to adjust the model to new circumstances. It remains to be seen whether the Nordic health care systems are flexible enough so that the main underlying principles can be upheld

Of course, it is not necessarily the case that everything needs to be changed. For example, given the circumstances, public hospitals are not necessarily a bad idea. From the international literature, it is far from clear which type of ownership is the most efficient. A priori, we need to consider the fact that inpatient care will often be a natural (local) monopoly in countries such as the Nordic countries. Quality of care often requires a certain volume of care, but in the thinly populated parts of the Nordic countries, this idea implies a single hospital. Furthermore, if one chooses to have a single payer with which the producer negotiates, then the obvious possibilities for opportunistic behaviour from this monopsonistic buyer of health care suggest that a hierarchical relationship may well be preferable to a market relationship (Williamson, 1985).

In view of the challenges ahead, it is not only the welfare state and the health care sector that needs to be flexible, but also the discipline of health economics. We envisage a future for health economics that entail extended use of both behavioural and experimental economics, in order to improve our understanding of individual health-related behaviour (life style), as well as the decision making of physician and other actors in the health care sector in general and in public systems like the Nordic ones in particular (Hansen et al., 2015). Such a re-focusing of health economics will also enable us to explore the relationship between the health care sector and its institutional context.

\section{Acknowledgements}

Financial support from the Nordic Research Council (project grant no: 229987/F10) is gratefully acknowledged.

\section{Companion papers in this issue of The Nordic Journal of Health Economics}

Alexandersen, N., Anell, A., Kaarboe, O., Lehto, J. S., Tynkkynen, K. and Vrangbæk, K. "The development of voluntary private health insurance in the Nordic countries".

Ásgeirsdóttir, T., Gerdtham, UG. "Health behaviour in the Nordic countries".

Iversen, T., Anell, A., Häkkinen, U., Kronborg, C., Olafsdóttir, T. "Coordinatioon of care in the Nordic countries".

Olsen, K. R., Anell, A., Häkkinen, U., Iversen, T., Olafsdóttir, T., Sutton, M. "General practice in the Nordic countries."

\section{References}

Alban, A. and Christiansen, T. (eds). (1995). The Nordic Lights. New initiatives in health care systems. Odense: Odense University Press.

${ }^{25}$ On Sweden, see Saltman (2015). 
Alm, J., Torgler, B. (2004). Estimating the determinants of tax morale. Proceedings. Annual conference on taxation and Minutes of the annual meeting of the National Tax Association 97, 269-274.

Anell, A. (2014). Vilken ojämlikhet är mest rättvis? Patientinflytande och egenavgifter i svensk vård. Uppdrag Välfärd.

Anell A, Glenngård, A. H., Merkur, S. (2012). Sweden. Health system review. Health System in Transition 14(5): 1-159.

Arrow, K., (1963). Uncertainty and the welfare economics of medical care, American Economic Review 53, 941-73.

Bergh, A. and Erlingsson, G. Ó. (2008). Liberalization without retrenchment: understanding the consensus on Swedish welfare state reforms. Scandinavian Political Studies 32:71-93.

Bergh, A., Bjørnskov, C. (2011). Historical Trust Levels Predict the Current Size of the Welfare State. Kyklos 64, 1-19.

Bjørnskov, C. (2006). Determinants of generalized trust. A cross-country comparison. Public Choice 130:1-21

Bjørnskov, C., Svendsen, G. T. (2013). Does social trust determine the size of the welfare state? Evidence using historical identification. Public Choice 157, 269-286

Christiansen, T. (2014). New Public Management in the Danish health care system. In A. J. Culyer and G. Kobelt (eds), Portrait of a health economist: Essays by colleagues and friends of Bengt Jönsson. Lund, Sweden, pp. 25-3.

Coast, J. (2001). Citizens, their agents and health care rationing: an exploratory study using qualitative methods. Health Economics 10, 159-174

Culyer, A. J. (1980). The poltical economy of social policy. Oxford: Martin Robertson.

Danzon, P. M. (1994). The Swedish patient compensation system: myths and realities. International Review of Law and Economics 14, 453-66.

Dreher, A. (2006). Does globalization affect growth? Evidence from a new index of globalization. Applied Economics, 38(10), 1091-1110.

Dreher, A., Gaston, N., and Martens, P. (2008). Measuring globalization - Gauging its consequences. New York: Springer.

Evans, R. G. (1984). Strained mercy. The economics of Canadian health care. Toronto: Butterworths.

Feng, Y., Pistolatto, M., Charlesworth, A. et al. (2014). Association between market concentration of hospitals and patient health gain following hip replacement surgery. Journal of Health Services Research \& Policy 20, 11-17.

Gaynor, M., Moreno-Serra, R., and Propper, C. (2010). Death by market power, NBER Working Paper 16164.

Gravelle, H., Smith, P. \& Xavier, A. (2003). Performance signals in the public sector: the case of health care. Oxford Economic Papers 55, 81-103.

Gravelle, H., Santos, R., Siciliani, L., Goudie, R. (2012). Hospital quality competition under fixed prices. CHE Research Paper 80. The University of York.

Grundtvig, N. F. S. (1820). Langt højere bjerge så vide på jord. Højskolesangbogen, various editions.

Gwartney, J., Lawson, R., and Hall, J.C. (2012). Economic Freedom of the World: 2012 Annual Report. The Fraser Institute. Data retrieved from www.freetheworld.com. June 24th, 2015.

Hansen, F., Anell, A., Gerdtham, U., Lyttkens, C. H. (2015). The future of health economics: the potential of behavioral and experimental economics. The Nordic Journal of Health Economics $3,68-86$.

Hansson, I., and Stuart, C. (1987). Tax revenue and the marginal cost of public funds in Sweden, Journal of Public Economics 27, 331-353. 
Henrich, J., Heine, S. J., Norenzayan, A. (2010). The weirdest people in the world? Behavioral and brain science 33, 61-135.

Häkkinen, U., Jonsson, P. M. (2009). Harnessing diversity of provision. In Magnussen, J., Vranæk, K., Saltman, R. B. (eds), Nordic Health Care Systems: Recent reforms and current policy changes. Berkshire: Open University Press, 198-213.

ICRG, (2012). International Country Risk Guide Methodology, Corruption. The PRS Group: East Syracuse, NY.

Iversen, T. (2011). Vägval i Norden - en ESO-rapport om skillnader och likheter i Norden. Rapport till Expertgruppen för studier i offentlig ekonomi. 2011:7.

Joumard, I., André, C., Nicq, C. (2010). Health care systems. Efficiency and institutions. OECD.

Kittelsen, S., Anthun, K. Goude, F. et al. (2015). Cost and quality at the hospital level in the Nordic countries. Health Economics on line.

Klausen, K.K., Ståhlberg, K. (1998). New public management $i$ Norden. Odense:Odense universitetsforlag.

Levi, M. (1988). Of rule and revenue. London: University of California Press.

Luttmer, E. F. P., Singhal, M.. (2014). Tax morale. NBER Working Paper Series 20458.

Lyttkens, C H. (2010). Sjukvårdens långsiktiga finansiering. In Anell, A and Gerdtham, U G, Vårdens utmaningar, SNS Välfärdsrapport 2010. Stockholm: SNSFörlag, 114-147.

Lyttkens, C.H. (2015). A reflection on Richard B. Saltman 'Structural patterns in Swedish health policy'. Health Economics, Policy and Law 10, pp 217-219.

Magnussen, J., Vrabaek, K., Saltman, R.B. (eds) (2009). The Nordic Health care systems. Recent reforms and current policy challenges. Berkshire: Open University Press.

Martin, S. Smith, P. C. (2003). Using panel methods to model waiting times for National Health Service. Journal of the Royal Statistics Society 166, 369-387.

Medin, E., Häkkinen, U., Linna, M. et al. (2013). International hospital productivity comparisons; experiences from the Nordic countries. Health Policy 112, 80-87.

Merton., R. K. (1936). The unanticipated consequences of purposive action, American Sociological Review 1, 894-904.

North, D .C. (1981). Structure and change in economic history. New York; W. W. Norton \& Company.

North, D. C. (1990). Institutions, institutional change and economic performance. New York: Cambridge University Press.

OECD. 2011. Society at a Glance: OECD Indicators. OECD Publishing.

OECD. 2013a. Health at a glance: OECD indicators. OECD Publishing.

OECD . 2013b. Regions at a Glance: OECD Indicators. OECD Publishing.

OECD 2013c. Tax and development. What drives tax moral?

OECD 2014a, Society at a Glance: OECD indicators. OECD Publishing.

OECD. 2014b. National Accounts at a Glance: OECD indicators. OECD Publishing.

OECD 2015. Gini coefficients data 2012. OECD.Stat. url: http://stats.oecd.org/.

Patsiurko, N. (2012). Measuring cultural diversity: ethnic, liinguistic and religious fractionalization in the OECD. Ethnic and racial studies 35, 195.217.

Persson, T., Tabellini, G. (2009). Democratic capital: The nexus of political and economic change. American Economic Journal: Macroeconomics, 1(2), 88-126.

Petersen, J. H. (2004). Velfærdsstatens krav til dig! In J. H.Petersen and K. Petersen (eds): 13 udfordringer til den danske velfærdsstat, Syddansk Universitetsforlag 
Propper, C. (1995). The disutility of time spent on the United Kingdom's National Health Service Waiting List. Journal of Human Resources 30, 677-700

Saltman, Richard B. (2015). Structural patterns in Swedish health policy: a 30-year perspective. Health Economics, Policy and Law 10, pp 195-215.

Siciliani, L. Moran, V., Borowitz, M. (2014). Measuring and comparing health care waiting times in OECD countries. Health Policy 118, 292-303.

Tinghög, G., Andersson, D., Tinghög, P., Lyttkens, C. H. (2014). Horizontal inequality by rationing by waiting lists, International Journal of Health Services 44, 169-184.

Tinghög, G., Carlsson, P., Lyttkens, C. H. (2010). Individual responsibility for what? A conceptual framework for exploring the suitability of private financing in a publicly funded health-care system, Health Economics, Policy and Law 5, 201-223.

Torgler, B. (2005). Tax morale and direct democracy. European Journal of Political Economy 21, 525-531.

Toth, F. (2010). Is there a Southern European Model? West European Politics 33, 325-343.

Trägårdh, L. (2015). Folkuniversitetets roll i det civila samhället. Uppsala: Fyris tryck AB.

Van Doorslaer, E., Masseri, C., Koolman, X. (2006). Inequalities in access to medicl care by income in developed countries. CMAJ174, 177-183.

Weesie, J., Wippler, R. (1986). Cumulative effects of sequential decisions in organszations, in Diekmann, A., Mitter, P. (eds), Paradoxical effects of social behaviour. Essays in honour of Anatol Rapoport. Heidelberg: Physica- Verlag, 257-279.

Williamson, Oliver E. (1985). The economic institutions of capitalism. New York: The Free Press.

(C) 2016 by the author(s). This article is an open access article distributed under the terms and conditions of the Creative Commons Attribution license (http://creativecommons.org/licenses/by/4.0/). 